ISBN 978-81-933894-1-6

5th International Conference on Chemical, Agricultural, Biological and Environmental Sciences

(CAFES-17)

Kyoto (Japan) April 18-19, 2017

\title{
Synthesis of Green Lubricant from Luffa (Luffa Cylindrica) Seed Oil for Automotive Gear Application
}

\author{
Orhevba, B.A ${ }^{1}$, Musa, $\mathrm{U}^{2}$., Garba, M.U ${ }^{2}$, Ndayako, M.K ${ }^{3}$ and Udeigbo Onyeka ${ }^{1}$ \\ ${ }^{1}$ Department of Agricultural and Bioresources Engineering Federal University of Technology, P.M.B 65, Gidan Kwano \\ Campus, Minna, Nigeria \\ ${ }^{2}$ Department of Chemical Engineering Federal University of Technology, P.M.B 65, Gidan Kwano Campus, Minna, , \\ Nigeria. \\ ${ }^{3}$ Scientific Equipment Development Institute (SEDI), Tagwai Dam, Institute (SEDI), Minna, Nigeria. \\ Corresponding Author: umar.musa@ futminna.edu.ng
}

\begin{abstract}
This paper presents the synthesis and characterization of biolubricant from luffa seed oil seed. The oil was extracted from luffa seed using solvent extraction and the extracted oil was characterized to determine some its properties. The oil was converted to biodiesel via acid - alkaline transesterification. Biolubricant was then produced further from transesterification of biodiesel with ethylene glycol at a temperature of $105{ }^{\circ} \mathrm{C}$, ethylene glycol to biodiesel of 3.9:1, reaction time of 70mins and catalyst concentration of 1wt\%. The resulting biolubricant was characterized for its lubricating characteristics. The result of characterization of the biolubricant compares favourably with the ISO VG standard thereby establishing the potential of the biolubricant as automotive light gear oil.
\end{abstract}

Keywords: Transesterification, biodiesel, biolubricant, vegetable oil, automotive, gear oil

\section{Introduction}

Mineral based oil lubricant account for $85-90 \%$ of the world's lubricant production [1]. The dependence on petroleum crude oil as a major source mineral base in the production of lubricants and other industrial fluid has led to several problems like shortage in supply, increasing cost and environmental health hazards [2]. The use of renewable resources in industrial applications is presently receiving considerable attention worldwide due to rapid industrialization and population growth. Vegetable oils are widely acknowledged as the most viable alternatives to petroleum based mineral oil because they are biodegradable, possesses higher flash point, excellent viscosity index, improved lubricity and lower volatility. However, pure vegetable oils cannot be used directly as base oils for various applications due to its low thermo-oxidative properties, hydrolytic stability, and poor cold flow behaviour [3].

Transesterification is the most effective technique for chemically modification of vegetable oil into biolubricant. In transesterification of vegetable oil for biolubricant synthesis, biodiesel is first produced as an immediate product. The biodiesel is further reacted with a polyol to produce the desired lubricant. The reaction with polyol is meant to eliminate the hydrogen atom in $\beta$-position of the vegetable oil or animal fat which will lead to substantial improvement in the thermo-oxidative properties of bio-based lubricant [4]. According to Wang et al [5] transesterification as a technique for biolubricant synthesis is superior to other techniques owing to its lower capital and energy consumption. Bio lubricants are lubricants produced from a variety of plant or animal oils.

Research have shown that biolubricant possess higher lubricity (2 to 4 times) than petroleum based lubricant. It is characterized with good adhesive properties than mineral based lubricant [6]. The higher lubricity of biolubricant leads to more power, better fuel economy and lower friction losses [6]. It also has low volatility 
thereby resulting in to higher flash point and reduced exhaust emission [7]. Numerous studies have reported the chemical modification of different vegetable oil for biolubricant synthesis [8].

The luffa plant is a free and rapid growing annual plant grown in virtually all parts of the country. Luffa belongs to the family cucurbitaceae, a group of plants which includes gourds, cucumbers and pumpkins [9]. The fruits of luffa cylindrica are smooth and cylindrical in shape. One mature luffa fruit will produce about 20-25 seeds or more. The fruits are eaten in some parts of the world like China and southern USA. Luffa is widely cultivated in Asia, India, Brazil and USA. Luffa finds wide applications as a packing medium, production of shoes mats, sound proof linings, bathing sponges, utensil cleaning sponges, adsorbent for heavy metal in waste water, and immobilization matrix for plant, algae, bacteria and yeast [10-11]. Luffa plant grows like weed; it needs little sunny and undisturbed area such as abandoned buildings or lands and also requires a firm climbing support [9]. Luffa sponge bears seeds that contains appreciable amount of oil. Luffa oil has been reportedly used for the production of biodiesel by a number of researchers [11-13]. To the best of the authors' knowledge there are no documented work on the production and characterization of biolubricant luffa seed oil. This study is aimed at production and characterization of biolubricant from luffa seed oil. The study will also help in establishing the potential of the oil as base oil for automotive gear oil production.

\section{Materials and Methods}

\subsection{Materials}

The seed was obtained from luffa sponge in Minna, Nigeria. Oil was extracted from the seed using sohxlet extractor and the oil content of the seed was determined. n-hexane, potassium hydroxide, methanol and Ethylene glycol were obtained from Sigma- Aldrich (St. Louis) and were of analytical grade.

\subsection{Methods}

\subsubsection{Esterification of oil}

The esterification of oil was carried out according to the methods reported by Mohammed - Dabo et al (2012) with slight modification. About $40 \mathrm{~g}$ of the oil was measured and poured into a round bottom flask and placed on a magnetic stirrer. The oil was heated up to a temperature of $60^{\circ} \mathrm{C}$. The mixture of $5 \% \mathrm{w} / \mathrm{w}$ tetraoxosulphate (iv) acid and $20 \% \mathrm{w} / \mathrm{w}$ methanol was heated to the same temperature and mixed together with the oil. The stirrer was set at $700 \mathrm{rpm}$ and timed. The oil sample was drawn at regular interval using pipette and was titrated against $0.1 \mathrm{~N} \mathrm{KOH}$ solutions in order to determine the \% FFA of oil.

\subsubsection{Tranesterification of oil to biodiesel}

The oil was charged into the reactor and heated to a temperature of $60{ }^{\circ} \mathrm{C}$. The mixture of methanol and $1 \%$ w/v of $\mathrm{KOH}$ was separately heated at the same temperature for $5 \mathrm{~min}$ and added slowly to the heated oil before turning on the stirrer. The reaction mixture of temperature of $60{ }^{\circ} \mathrm{C}$ was maintained for a specified reaction time. After this time, the mixture was poured into a separator for seperation into two distinct layers. The top layer which is Ester Phase (EP) containing the biodiesel and the bottom layer that is Glycerol phase (GP) that contains glycerol $(\mathrm{G})$, water $(\mathrm{W})$ and methanol $(\mathrm{M})$. The heavier glycerol layer will be drain off. The biodiesel layer was washed with equal volume of warm water at $45{ }^{\circ} \mathrm{C}$ until the wash water was neutral to litmus paper. This was followed by heating to remove any moisture present and dried over anhydrous $\mathrm{Na}_{2} \mathrm{SO}_{4}$. Finally the biodiesel content of the product was measured.

\subsection{Production of Bio lubricant}

About $40 \mathrm{~g}$ of luffa seed biodiesel was measured and placed into a two neck round bottom flask fitted with a thermometer, reflux condenser and vacuum pump. The flask was mounted on a magnetic stirrer hot plate. The reacting system was then heated to and maintained at $105{ }^{\circ} \mathrm{C}$. Ethylene glycol was added to the flask containing biodiesel in the ratio of 3.9:1 followed by the gentle addition of $\mathrm{KOH}$ catalyst to the mixture of ethylene glycol and biodiesel under vacuum condition. The reaction was maintained for 70 mins. 


\subsection{Characterization of Biodiesel and Bio lubricant}

The properties of the oil were characterized using AOACS standard while the biolubricant synthesized would be characterized according to the ASTM Standard [6].

\section{Results and Discussion}

\subsection{Properties of Luffa seed oil}

Table 1 shows the values of the properties of the oil. The acid value and FFA were 11.05 and 5.611 respectively.

TABLE I: The Properties of luffa seed oil

\begin{tabular}{ll}
\hline \hline Properties & Value \\
\hline Flash point $\left({ }^{\circ} \mathrm{C}\right)$ & $174 \pm 2.16$ \\
Acid value & $11.05 \pm 0.1$ \\
Free Fatty Acid & $5.61 \pm 0.05$ \\
Viscosity @ 31 & $17 \pm 0.19$ \\
\hline \hline
\end{tabular}

The FFA content of the oil needs to be reduced to $1 \%$ or below via esterification to avoid high saponification of oil. The viscosity of oil is $17 \mathrm{cSt}$ and must be reduced to be within $1.9-6.0 \mathrm{~mm}^{2} / \mathrm{s}$ to establish that biodiesel formed. The viscosity of $5.6 \mathrm{cSt}$ observed shown the effectiveness of the conversion of oil to biodiesel.

\subsection{Properties of Biodiesel and Bio lubricant}

Table II: Properties of Biodiesel and Biolubricant

\begin{tabular}{|c|c|c|c|c|c|c|c|}
\hline Properties & Biodiesel & This study & A & B & $\mathrm{C}$ & $\begin{array}{l}{ }^{*} \text { ISO VG } \\
32\end{array}$ & $\begin{array}{l}\text { ISO VG } \\
46\end{array}$ \\
\hline Flash Point $\left({ }^{\circ} \mathrm{C}\right)$ & $136 \pm 1.24$ & $255 \pm 1.87$ & 262 & - & - & 204 & 220 \\
\hline Pour Point $\left({ }^{\circ} \mathrm{C}\right)$ & $-6 \pm 1.63$ & $-4 \pm 0.71$ & 1.3 & -12 & -7 & -6 & -10 \\
\hline $\begin{array}{l}\text { Viscosity } \\
40^{\mp} \mathrm{C} \text { (Cst) }\end{array}$ & 5.6 & $181 \pm 1.08$ & 190 & 35.43 & 55.17 & $>28.8$ & $>41.4$ \\
\hline $\begin{array}{l}\text { Viscosity } \\
100^{5} \mathrm{C} \text { (Cst) }\end{array}$ & 1.9 & $73 \pm 2.12$ & 70 & 7.93 & 10.96 & $>4.1$ & $>4.1$ \\
\hline Viscosity Index & 255.12 & 420 & 397 & 206 & 195.22 & $>90$ & $>90$ \\
\hline
\end{tabular}

*Wang et al., 2014 [5] (A) Mohammed et al., 2015[7] (Neem oil biolubricant) (B) Dodos et al., 2011 [14] (Sesame oil biolubricant) $\quad$ (C) Bilal et al., 2013 [6] (Jatropha oil biolubricant)

Viscosity is an important property of lubricating oil. It measures the fluid resistance to flow at corresponding temperature. The viscosity of the biolubricant produced at a temperature of 40 and $100{ }^{\circ} \mathrm{C}$ were 181 and $73 \mathrm{cSt}$ respectively. This value is appreciable higher than $>28.8$ and $4.1 \mathrm{cSt}$ stipulated for ISO viscosity grade requirement for light gear oil. The result is an indication of higher viscosity index (VI) of the biolubricant which imply that the biolubricant produced can be efficiently used over a wide range of temperatures. The decrease viscosity with temperature can be linked to the decrease in force of attraction between the liquids molecule [15].

Viscosity Index is a dimensionless number used to characterize the range of the kinematic viscosity of a product with temperature. The higher the viscosity indexes the lower the viscosity and vice-versa. The oil with VI values higher than 130 have wide variety of engine application. The value observed in this study fulfils the ISO VG 46 and ISO VG220 standard specification for light gear oil. It is also higher than the VI of biolubricant derived from other vegetable oil as shown in Table 2.

Pour point determines the low temperature usability of a lubricant. The luffa biolubricant has a pour point of $-4^{\circ} \mathrm{C}$. This value is slightly higher than $-6^{\circ} \mathrm{C}$ stipulated for ISO VG 46 and ISO VG220 standard specification for light gear oil. It can also be observed from Table 2, that the pour point value observed in this work is appreciable lower than $1.3^{\circ} \mathrm{C}$ reported for neem oil based lubricant by Mohammed et al. [7]. This finding signifies that luffa biolubricant can be used at lower temperature without filter clogging.

Flash point is a criteria for determination of the flammability of a lubricant [8]. The flash point of the biolubricant derived from luffa oil is $255^{\circ} \mathrm{C}$. This flash point value is a remarkable improvement from $133^{\circ} \mathrm{C}$ for 
its corresponding biodiesel. This high flash point is as a result of chemical modification of the base oil. The result is satisfactorily within the range of $204-265^{\circ} \mathrm{C}$ stipulated for ISO VG 32 standard. The findings also shows close proximity to $262^{\circ} \mathrm{C}$ reported for neem oil biolubricant as depicted in Table 2. Luffa oil based lubricant can be considered to be free of methanol and therefore very safe from handling and storage point of view.

\section{Conclusion}

This study has demonstrated that selected plant oil has the potential for the production eco-friendly lubricant. The properties of the biolubricant produced show appreciable consistency with stipulated specification for automotive light gear oil. The study establishes the potential of luffa seed oil for synthesis of gear oil. The innovation in this manuscript is that it is one of the very first attempts to study the synthesis of biolubricant using luffa seed oil as base oil.

\section{References}

[1] J. Nie "Synthesis and evaluation of polyol based biolubricants from vegetable oils" M.ScThesis, University of Saskatchewan: Saskatoon, Canada; 2012.

[2] A.F. Roseli, M.T. Anna Leticia \& J.P. Kil (2011). Biodiesel Production and Quality, Biofuel's. Engineering Process Technology, Marco Aurelio D.B.S (Ed.). Intech, Available from http:// www.intechopen.com/books/biofuel-sengineering-process-technology/biodiesel-production-and-quality. pp. 221-240.

[3] V.B. Borugadda, \& V.V. Goud. Improved thermo-oxidative stability of structurally modified waste cooking oil methyl esters for bio-lubricant application, Journal of Cleaner Production, 2016, 112, pp. 4515-4524.

https://doi.org/10.1016/j.jclepro.2015.06.046

[4] K. Kamalakar, K.R .Amit , R.B.N. Prasad \& M.S.L. Karuna . Rubber seed oil-based biolubricant base stocks: A potential source for hydraulic oils. Industrial Crops and Products, 2013, 51, pp. 249- 257. https://doi.org/10.1016/j.indcrop.2013.08.058

[5] E. Wang, M. Xiang, S.Tang, R. Yan, Y. Wang, W.W. Riley \& M. J.T. Reaney. Synthesis and oxidative stability of trimethylolpropane fatty acid triester as a biolubricant base oil from waste cooking oil. Biomass and Bioenergy, 2014, 66, pp. 371-378.

https://doi.org/10.1016/j.biombioe.2014.03.022

[6] S. Bilal, I. Mohammed-Dabo, M. Nuhu, S.A. Kasim, I.H. Almustapha \& Y.A. Yamusa. Production of biolubricant from Jatropha curcas seed oil. Journal of Chemical Engineering and Materials Science. 2013,Vol. 4(6), pp. 72-79. https://doi.org/10.5897/JCEMS2013.0164

[7] N. Mohammed. "Synthesis of Biolubricant From Vegetable Oils". B.Sc Thesis, Department of Chemical Engineering, Ahmadu Bello University, Zaria, Nigeria, 2015.

[8] U. Musa, I.A.Mohammed, M.M. Sadiq, F. Aberuagba \& O.A Olurinde "Synthesis and Characterization of Trimethylolpropane-Based Biolubricants from in situ derived Castor oil Methyl Ester," in Proc. $45^{\text {th }}$ Annual Conference of Nigeria Society of Chemical Engineer (NSChE), 2015, pp. 248-253.

[9] O.M. Abayeh, , I.H. Garba, H.M. Adamu \& O.J. Abayeh. Quality Characteristics of Luffa Seed Oil. International Journal of Scientific and Engineering Research, 2013, 4(1), pp. 11-15.

[10] Y. Laidani, S. Hanini \& G. Henini. Use of fiber Luffa cylindrica for water treatment charged in copper. Study of the possibility of its regeneration by desorption chemical. Energy Procedia, 2011, 6, 381-388. https://doi.org/10.1016/j.egypro.2011.05.044

[11] I.O. Oboh \& E.O. Aluyor. Luffa cylindrica - An emerging cash crop. African, Journal of Agricultural Research, 2009, 4, pp. 684-688.

[12] V.I.E. Ajiwe, G.I. Ndukwe \& I.E .Anyadiegwu . Vegetable Diesel Fuels from Luffa Cylindrica oil, its methyl ester and ester-diesel blends. Chemclass. J. 2005, 1-4. Pp.2. 
[13] A. I . Bamgboye, \& O. O. Oniya. Fuel properties of loofah (Luffa cylindrica L.) biofuel blended with diesel, African Journal of Environmental Science and Technology, 2012, Vol. 6(9), pp. 346-352, Available online at http://www.academicjournals.org/AJEST DOI: 10.5897/AJEST11.364

[14] T. O. K. Audu, E. O. Aluyor, S. Egualeona, \& S.S. Momoh . Extraction and Characterization of Chrysophyllum albidum and Luffa cylindrica Seed Oils, Petroleum Technology Development Journal : An International Journal, 2013, $3(1), \mathrm{pp} 1-7$.

[15] G.S. Dodos, F. Zannikos \& L. Lois. Utilisation of sesame oil for the production of bio-base fuel and lubricants. In: Proceedings of the third International CEMEPE \& SECOTOX Conference Skiathos, 2011,

[16] F.U. Ozioko, Extraction and characterization of soybean oil based bio-lubricant. Assumption Univer J Technol ., 2012, 15(4), pp260-264. 